\title{
In Vitro Studies of Piperacillin, a New Semisynthetic Penicillin
}

\author{
DREW J. WINSTON,* DAISY WANG, LOWELL S. YOUNG, WILLIAM J. MARTIN, \\ AND WILLIAM L. HEWITT
}

\begin{abstract}
Division of Infectious Diseases, Department of Medicine; Department of Pathology; and Department of Microbiology and Immunology, UCLA Center for the Health Sciences, Los Angeles, California 90024
\end{abstract}

\author{
Received for publication 27 December 1977
}

\begin{abstract}
Piperacillin, a new semisynthetic penicillin, was compared with other semisynthetic penicillins, cephalosporins, and aminoglycosides by the agar dilution method against 3,600 isolates of facultative gram-negative bacilli, Bacteroides fragilis, and enterococci. At $64 \mu \mathrm{g} / \mathrm{ml}$, piperacillin inhibited $90 \%$ of the isolates in each group of organisms tested except for Escherichia coli (83\% inhibited by 64 $\mu \mathrm{g} / \mathrm{ml})$. Compared with carbenicillin, piperacillin had a 16 -fold increase in activity by weight against Pseudomonas aeruginosa and the enterococcus, an 8 -fold increase against Serratia marcescens, and a 4-fold increase against $B$. fragilis and Enterobacter species. Piperacillin was highly active against carbenicillinresistant Klebsiella pneumoniae and inhibited many aminoglycoside-resistant organisms. Except for $\boldsymbol{P}$. aeruginosa, the minimum bactericidal concentration of piperacillin was usually within one tube dilution of the minimum inhibitory concentration. Approximately one-third of the gram-negative bacilli were inhibited synergistically by piperacillin plus amikacin, but no synergy could be demonstrated against enterococci. Piperacillin's in vitro activity against gramnegative bacilli was similar to gentamicin's except that it also included $B$. fragilis, and piperacillin was decidedly superior to presently available penicillins against K. pneumoniae.
\end{abstract}

Piperacillin sodium, a new semisynthetic penicillin developed by Ueo et al. (12), has a broad spectrum of in vitro activity against gram-negative bacteria, including Pseudomonas aeruginosa and Klebsiella pneumoniae. Its major potential clinical usefulness would appear to be related to its wider spectrum of activity than other beta-lactam antimicrobial agents and its lower toxicity than the aminoglycoside drugs. Thus, in vitro testing was conducted at the UCLA Center for the Health Sciences against 3,600 clinical isolates of gram-negative bacilli and enterococci, and the in vitro activity of piperacillin was compared with that of other semisynthetic penicillins (carbenicillin, ampicillin), cephalosporins (cephalothin, cefoxitin), and aminoglycosides (gentamicin, amikacin).

\section{MATERIALS AND METHODS}

Organisms. The in vitro susceptibilities of 3,549 clinical isolates of facultative gram-negative bacilli, 35 isolates of Bacteroides fragilis, and 15 strains of grampositive enterococci were evaluated between April and September 1977. All organisms were cultured from clinical material in the Clinical Microbiology Laboratories of the UCLA Center for the Health Sciences and identified by standard criteria $(3,4,7,10,11)$. The standard reference strains of Escherichia coli ATCC
25922, Pseudomonas aeruginosa ATCC 27853 ("Boston" strain), and Staphylococcus aureus ATCC 25923 were always tested as internal controls with the facultative organisms. Two control strains of $B$. fragilis (UCLA no. 55073 and 55711) were tested with each group of anaerobic isolates. The susceptibilities of 27 gentamicin-resistant (minimum inhibitory concentration $[\mathrm{MIC}] \geq 16 \mu \mathrm{g} / \mathrm{ml}$ ) organisms and 13 amikacinresistant (MIC $\geq 32 \mu \mathrm{g} / \mathrm{ml}$ ) organisms to piperacillin and carbenicillin were also evaluated. The gentamicinresistant organisms were isolated from patients at the UCLA Center for the Health Sciences and the Wadsworth Veterans Administration Hospital, Los Angeles; the amikacin-resistant organisms were all permeability mutants obtained from Kenneth Price of Bristol Laboratories, Syracuse, N.Y.

Antimicrobial agents. Laboratory-standard powders were provided as follows: piperacillin (lot no. 722385; potency, $910 \mu \mathrm{g} / \mathrm{ml}$ ) from Martin Forbes of Lederle Laboratories, Pearl River, N.Y.; carbenicillin (lot no. 6J077-36QCS; potency, $869 \mu \mathrm{g} / \mathrm{ml}$ ) from Pfizer Laboratories, New York, N.Y.; gentamicin (lot no. GMC-4-M-6044; potency, $571 \mu \mathrm{g} / \mathrm{mg}$ ) from the Schering Corp., Bloomfield, N.J.; cephalothin (lot no. P86614; potency, $946 \mu \mathrm{g} / \mathrm{mg}$ ) from Eli Lilly and Co., Indianapolis, Ind.; ampicillin (lot no. 75F1836; potency, $849 \mu \mathrm{g} / \mathrm{mg}$ ) and amikacin (lot no. 75F1598; potency, $850 \mu \mathrm{g} / \mathrm{mg}$ ) from Bristol Laboratories; and cefoxitin (lot no. C-E 126; potency, $949 \mu \mathrm{g} / \mathrm{mg}$ ) from Merck, Sharp, and Dohme, West Point, $\mathrm{Pa}$. 
Procedures. Antimicrobial susceptibility testing of facultative organisms by the agar dilution method was performed by methods as previously described $(1,13)$. Mueller-Hinton medium (control no. 640657, Difco Laboratories, Detroit, Mich.) with $1.7 \mathrm{~g}$ of agar per liter ( $\mathrm{pH}$ 7.4) was prepared to contain twofold increments of each antimicrobial agent. Susceptibility testing of the enterococci also incorporated human blood in agar at a concentration of $3 \%$. The following ranges of drug concentrations were tested: piperacillin, 8.0 to $256 \mu \mathrm{g} / \mathrm{ml}$; carbenicillin, 16 to $256 \mu \mathrm{g} / \mathrm{ml}$; gentamicin, 0.25 to $8.0 \mu \mathrm{g} / \mathrm{ml}$; ampicillin, 2.0 to $16 \mu \mathrm{g} / \mathrm{ml}$; and cephalothin, 0.5 to $16 \mu \mathrm{g} / \mathrm{ml}$. An inoculum of approximately $10^{4}$ organisms diluted from broth cultures in the logarithmic phase of growth was used.

Anaerobic bacteria were tested by the agar dilution method, using Wilkins-Chalgren medium ( $\mathrm{pH}$ 7.2) (15) and the following ranges of drug concentrations: piperacillin, 0.25 to $128 \mu \mathrm{g} / \mathrm{ml}$; carbenicillin, 8.0 to 128 $\mu \mathrm{g} / \mathrm{ml}$; and cefoxitin, 0.5 to $64 \mu \mathrm{g} / \mathrm{ml}$. An inoculum of $10^{5}$ organisms was used after a 72-h incubation on blood agar and an 18- to 24-h incubation in Schaedler broth at $37^{\circ} \mathrm{C}$. The agar plates were read after incubation at $37^{\circ} \mathrm{C}$ in a GasPak jar (BioQuest, Cockeysville, Md.) for $48 \mathrm{~h}$.

Broth dilution susceptibility tests were performed with Mueller-Hinton broth medium (pH 7.4) (control no. 631999, Difco Laboratories) and an inoculum of 5 $\times 10^{5}$ organisms $(1,2)$. The influence of the inoculum size on the MIC of piperacillin and carbenicillin was also determined by the broth dilution method. Twenty isolates were tested at inocula of $1 \times 10^{3}, 1 \times 10^{5}$, and $1 \times 10^{7}$ colony-forming units $(\mathrm{CFU}) / \mathrm{ml}$.

The synergistic activity of piperacillin plus amikacin against gram-negative bacilli and enterococci was assessed by the agar dilution method described by Sabath and co-workers (9). Synergism was defined as a fourfold reduction in the MIC for each drug by the combination of antimicrobial agents (14).

Criteria for susceptibility. Isolates were considered susceptible if they were inhibited at or below the peak serum level usually achieved during administration of each antimicrobial agent to hospitalized patients or normal volunteers. In our laboratories, the following mean peak serum levels are usually obtained after intravenous administration: carbenicillin, 128 $\mu \mathrm{g} / \mathrm{ml}$ at a dose of $5.0 \mathrm{~g}$; ampicillin, $16 \mu \mathrm{g} / \mathrm{ml}$ at a dose of $2.0 \mathrm{~g}$; cephalothin, $16 \mu \mathrm{g} / \mathrm{ml}$ at a dose of $2.0 \mathrm{~g}$; gentamicin, $4 \mu \mathrm{g} / \mathrm{ml}$ at a dose of $1.5 \mathrm{mg} / \mathrm{kg}$; and cefoxitin, $32 \mu \mathrm{g} / \mathrm{ml}$ at a dose of $2.0 \mathrm{~g}$. Data made available from Lederle Laboratories (private communication from Vincent A. Joy) indicate that peak serum levels achieved after intravenous administration of $4 \mathrm{~g}$ of piperacillin are at least $128 \mu \mathrm{g} / \mathrm{ml}$. To relate results of susceptibility tests to achievable blood levels, the inhibitory indexes were calculated for each antimicrobial agent tested. The inhibitory index is defined as the ratio between the mean peak serum level of each antimicrobial agent and the MIC in agar required to inhibit two-thirds of each group of organisms (16).

\section{RESULTS}

Table 1 summarizes the MICs and minimum bactericidal concentrations (MBCs) for the standard reference strains as determined by agar and

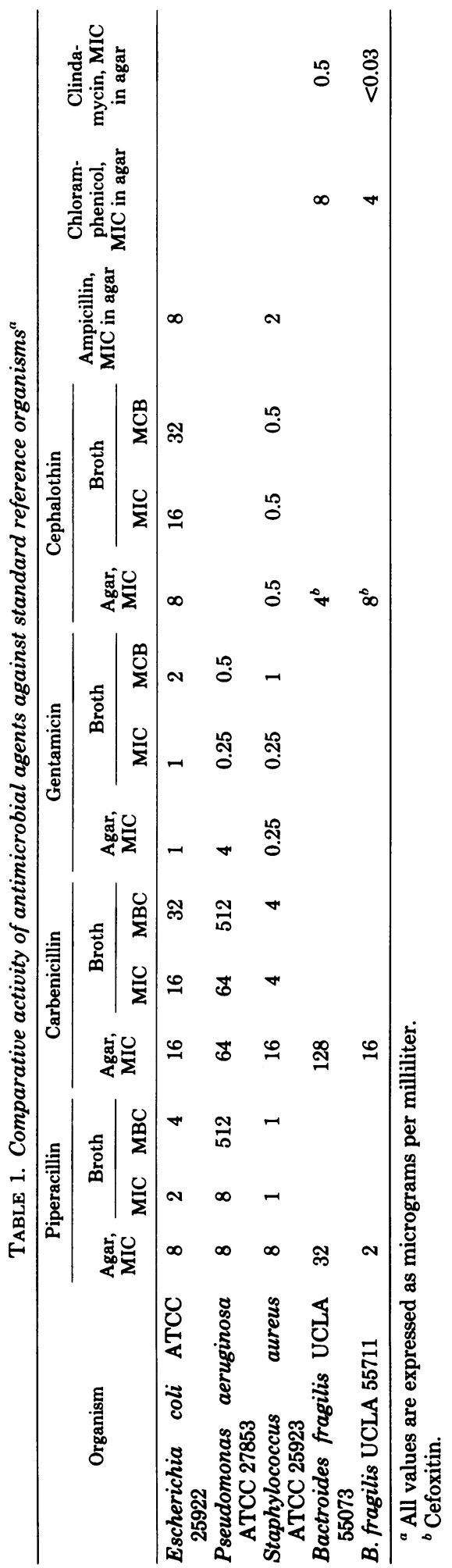


broth dilution methods. These values differed by no more than one dilution on repetitive testing. For $E$. coli ATCC 25922, the MBC was usually one dilution higher than the MIC for each antimicrobial agent tested. However, for $P$. aeruginosa ATCC 27853, the MBCs of piperacillin and carbenicillin were several dilutions higher than the MICs. Such a spread between the MIC and MBC was not seen with gentamicin. Except for gentamicin, the MIC and MBC of each antimicrobial agent tested against $S$. aureus 25923 were identical.

The results of the in vitro susceptibility testing of isolates to piperacillin alone are summarized in Table 2. Except for Acinetobacter calcoaceticus, $50 \%$ of the isolates in each group of organisms tested were inhibited by $8 \mu \mathrm{g} / \mathrm{ml}$. Similarly, $90 \%$ or more of the isolates in each group were inhibited by $64 \mu \mathrm{g} / \mathrm{ml}$ except for $E$. coli.

The comparative activities of piperacillin, carbenicillin, and other antimicrobial agents against specific gram-negative bacilli and the enterococcus are also summarized in Table 2 . Generally, piperacillin was more active on a weight basis than carbenicillin against all gram-negative and enterococcal organisms tested except $E$. coli. This increased activity of piperacillin over carbenicillin was most notable for $K$. pneumoniae (32-fold), $P$. aeruginosa (more than 8-fold), enterococcus (16-fold), and Serratia marcescens (more than 4-fold). Compared with gentamicin, piperacillin was more active against $S$. marcescens but less active against $E$. coli. Gentamicin inhibited only $50 \%$ of the $P$. aeruginosa isolates at $4 \mu \mathrm{g} / \mathrm{ml}$, but susceptibility results for $P$. aeruginosa against aminoglycosides are known to be highly medium dependent (5).

Since only piperacillin and gentamicin showed in vitro activity against all the facultative isolates tested (excluding enterococcus), these two antimicrobial agents are compared in Table 3. As shown, piperacillin's in vitro activity was similar to or better than gentamicin's for all organisms except $E$. coli (14\% resistant to piperacillin but only $3 \%$ resistant to gentamicin).

Susceptibility results using Mueller-Hinton broth correlated well with the agar dilution method for piperacillin against all organisms except Proteus (Table 4).

The MBC was within one dilution of the MIC for approximately $80 \%$ of the isolates tested against piperacillin, carbenicillin, and gentamicin (Table 5). Ninety-two percent of the organisms tested against cephalothin had a MBC within one dilution of the MIC. For P. aeruginosa, only $32 \mu \mathrm{g}$ of piperacillin per $\mathrm{ml}$ was needed to inhibit all 16 isolates tested compared with $512 \mu \mathrm{g} / \mathrm{ml}$ for carbenicillin. On the other hand, both piperacillin and carbenicillin required $512 \mu \mathrm{g} / \mathrm{ml}$ to kill all 16 isolates of $P$.

TABLE 2. Comparison of piperacillin and other antimicrobial agents against clinical isolates

\begin{tabular}{|c|c|c|c|c|c|c|c|}
\hline \multirow{2}{*}{ Organism } & \multirow{2}{*}{$\begin{array}{c}\% \\
\text { strains } \\
\text { inhibited }\end{array}$} & \multicolumn{6}{|c|}{ Concn $(\mu \mathrm{g} / \mathrm{ml})$ required to inhibit given $\%$ of strains } \\
\hline & & $\begin{array}{l}\text { Piper- } \\
\text { acillin }\end{array}$ & $\begin{array}{l}\text { Carben- } \\
\text { icillin }\end{array}$ & $\begin{array}{l}\text { Genta- } \\
\text { micin }\end{array}$ & $\begin{array}{l}\text { Ampi- } \\
\text { cillin }\end{array}$ & $\begin{array}{c}\text { Cephalo- } \\
\text { thin }\end{array}$ & $\begin{array}{c}\text { Cefox- } \\
\text { itin }\end{array}$ \\
\hline \multirow[t]{2}{*}{ Klebsiella pneumoniae $(549)^{a}$} & 50 & 8 & 256 & 1 & & 8 & \\
\hline & 90 & 64 & $>256$ & 1 & & 16 & \\
\hline \multirow[t]{2}{*}{ Pseudomonas aeruginosa (656) } & 50 & 8 & 64 & 4 & & & \\
\hline & 90 & 32 & $>256$ & $>8$ & & & \\
\hline \multirow[t]{2}{*}{ Enterococcus (15) } & 50 & 8 & 64 & & & & \\
\hline & 90 & 8 & 128 & & & & \\
\hline \multirow[t]{2}{*}{ Escherichia coli $(1,496)$} & 50 & 8 & 16 & 1 & 8 & 8 & \\
\hline & 90 & 256 & $>256$ & 4 & $>16$ & 16 & \\
\hline \multirow[t]{2}{*}{ Serratia marcescens(73) } & 50 & 8 & 32 & 1 & & & \\
\hline & 90 & 64 & $>256$ & 8 & & & \\
\hline \multirow[t]{2}{*}{ Bacteroides fragilis (35) } & 50 & 4 & 16 & & & & 8 \\
\hline & 90 & 32 & 128 & & & & 16 \\
\hline \multirow[t]{2}{*}{ Enterobacter cloacae (202) } & 50 & 8 & 16 & 1 & & & \\
\hline & 90 & 16 & 128 & 1 & & & \\
\hline \multirow[t]{2}{*}{ Enterobacter aerogenes (62) } & 50 & 8 & 16 & 1 & & & \\
\hline & 90 & 32 & 128 & 1 & & & \\
\hline \multirow[t]{2}{*}{ Proteus mirabilis (338) } & 50 & 8 & 16 & 1 & 2 & 8 & \\
\hline & 90 & 8 & 64 & 4 & 16 & 16 & \\
\hline \multirow[t]{2}{*}{ Indole-positive Proteus (84) } & 50 & 8 & 16 & 1 & & & \\
\hline & 90 & 8 & 32 & 1 & & & \\
\hline \multirow[t]{2}{*}{ Citrobacter freundii (51) } & 50 & 8 & 16 & 1 & & & \\
\hline & 90 & 8 & 256 & 1 & & & \\
\hline \multirow[t]{2}{*}{ Acinetobacter calcoaceticus (38) } & 50 & 16 & 64 & 4 & & & \\
\hline & 90 & 32 & 256 & $>8$ & & & \\
\hline
\end{tabular}

${ }^{a}$ Number of clinical isolates tested. 
TABLE 3. Comparative activity of piperacillin and gentamicin as determined by agar dilution

\begin{tabular}{|c|c|c|c|}
\hline \multirow[b]{2}{*}{ Organism } & \multirow[b]{2}{*}{ No. } & \multicolumn{2}{|c|}{$\%$ inhibited by: } \\
\hline & & $\begin{array}{l}\text { Piper- } \\
\text { acillin } \\
(128 \\
\mu \mathrm{g} / \mathrm{ml})^{a}\end{array}$ & $\underset{(4 \mu \mathrm{g} / \mathrm{ml})^{\alpha}}{\text { Gentamicin }}$ \\
\hline Escherichia coli . . . . . . . & 1,496 & 86 & 97 \\
\hline Pseudomonas aeruginosa & 656 & 97 & 44 \\
\hline Klebsiella pneumoniae ... & 549 & 94 & 98 \\
\hline Enterobacter cloacae & 202 & 96 & 99 \\
\hline Enterobacter aerogenes & 62 & 100 & 95 \\
\hline Serratia marcescens ... & 73 & 95 & 81 \\
\hline Proteus mirabilis . . . . & 338 & 99 & 97 \\
\hline Indole-positive Proteus & 84 & 100 & 100 \\
\hline Citrobacter freundii ....... & 51 & 100 & 100 \\
\hline Acinetobacter calcoaceticus . & 38 & 100 & 61 \\
\hline
\end{tabular}

${ }^{a}$ Mean peak serum level.

TABLE 4. Comparison of piperacillin agar and broth MICs

\begin{tabular}{|c|c|c|c|}
\hline \multirow[t]{2}{*}{ Organism } & \multirow[t]{2}{*}{$\begin{array}{c}\% \text { of } \\
\text { strains } \\
\text { inhibited }\end{array}$} & \multicolumn{2}{|c|}{$\begin{array}{c}\text { Concn }(\mu \mathrm{g} / \mathrm{ml}) \\
\text { required to } \\
\text { inhibit given } \\
\% \text { of strains }\end{array}$} \\
\hline & & Agar & Broth \\
\hline Klebsiella pneumoniae & 50 & 8 & 8 \\
\hline$(31)^{a}$ & 90 & 16 & 16 \\
\hline Pseudomonas aerugi- & 50 & 8 & 8 \\
\hline nosa (36) & 90 & 32 & 32 \\
\hline \multirow[t]{2}{*}{ Enterococcus (6) } & 50 & 8 & 8 \\
\hline & 90 & 8 & 8 \\
\hline \multirow[t]{2}{*}{ Escherichia coli (29) } & 50 & 8 & 8 \\
\hline & 90 & 32 & 64 \\
\hline \multirow[t]{2}{*}{ Serratia marcescens (23) } & 50 & 8 & 8 \\
\hline & 90 & 8 & 8 \\
\hline \multirow{2}{*}{$\begin{array}{l}\text { Enterobacter cloacae } \\
\text { (11) }\end{array}$} & 50 & 8 & 16 \\
\hline & 90 & 16 & 32 \\
\hline \multirow{2}{*}{$\begin{array}{l}\text { Enterobacter aerogenes } \\
\text { (6) }\end{array}$} & 50 & 32 & 16 \\
\hline & 90 & 64 & 32 \\
\hline \multirow[t]{2}{*}{ Proteus mirabilis (14) } & 50 & 8 & 16 \\
\hline & 90 & 32 & 256 \\
\hline Indole-positive & 50 & 8 & 8 \\
\hline Proteus (17) & 90 & 8 & 256 \\
\hline
\end{tabular}

${ }^{a}$ Number of isolates tested. aeruginosa. Thus, a 4- to 32-fold difference between the MIC and MBC was observed for piperacillin against $56 \%$ of the $P$. aeruginosa isolates tested, whereas for carbenicillin, because of the higher MICs, a 4- to 8-fold difference between MIC and MBC was seen for only $12 \%$ of the same isolates. Such a large spread between the MIC and MBC for piperacillin was seen infrequently with other organisms. Sixty percent of the $E$. coli tested against carbenicillin had an MBC-to-MIC ratio of 1 or 2, whereas only $40 \%$ of the indole-positive Proteus species had an MBC-to-MIC ratio of 1 or 2 for gentamicin.

The effect of inoculum size on the broth MICs of piperacillin and carbenicillin is summarized in Table 6. For piperacillin, the inoculum effect was relatively small at low inocula $(100 \%$ of the isolates inhibited by $128 \mu \mathrm{g} / \mathrm{ml}$ at both $10^{3}$ and $10^{5} \mathrm{CFU} / \mathrm{ml}$ ) but much greater at higher inocula (only $25 \%$ of the isolates inhibited by $128 \mu \mathrm{g} / \mathrm{ml}$ at $10^{7} \mathrm{CFU} / \mathrm{ml}$ ). For carbenicillin, a similar inoculum effect was observed $(25,20$, and $10 \%$ of the isolates inhibited by $128 \mu \mathrm{g} / \mathrm{ml}$ at inocula of $10^{3}, 10^{5}$, and $10^{7} \mathrm{CFU} / \mathrm{ml}$, respectively).

Since the activity by weight of an antimicrobial agent may be less meaningful than the relationship between potency by weight and the achievable peak serum levels, the inhibitory index as previously defined was calculated for each group of organisms and each antimicrobial agent. Piperacillin had a significantly higher inhibitory index than carbenicillin for $P$. aeruginosa, $E$. coli, $K$. pneumoniae, $S$. marcescens, $B$. fragilis, and the enterococcus (Table 7). For $P$. mirabilis, indole-positive Proteus, and the Enterobacter species, the indexes for piperacillin and carbenicillin were similar. Piperacillin also had a significantly higher index than cephalothin against $K$. pneumuniae. For $B$. fragilis, the piperacillin index was markedly higher than the cefoxitin index.

Only 5 of 27 gentamicin-resistant organisms were inhibited by both carbenicillin and pipera-

TABLE 5. Comparison of MIC and $M B C$

\begin{tabular}{|c|c|c|c|c|c|}
\hline \multirow{2}{*}{ Organism } & \multirow{2}{*}{$\begin{array}{l}\text { No. } \\
\text { tested }\end{array}$} & \multicolumn{4}{|c|}{ No. of isolates having MBC/MIC ratio of 1 or 2} \\
\hline & & Piperacillin & Carbenicillin & Gentamicin & Cephalothin \\
\hline Pseudomonas aeruginosa. & 16 & $7(44)^{a}$ & $14(88)$ & $14(88)$ & \\
\hline Klebsiella pneumoniae & 7 & $7(100)$ & $6(86)$ & $7(100)$ & $5(71)$ \\
\hline Escherichia coli ...... & 15 & $14(93)$ & $9(60)$ & $14(93)$ & $12(80)$ \\
\hline Serratia marcescens & 17 & $15(88)$ & $17(100)$ & $12(71)$ & \\
\hline Enterococcus ....... & 6 & $6(100)$ & $6(100)$ & & \\
\hline Enterobacter cloacae . . & 9 & $8(89)$ & $6(67)$ & $7(78)$ & \\
\hline Enterobacter aerogenes & 5 & $5(100)$ & $5(100)$ & $3(60)$ & \\
\hline Proteus mirabilis ...... & 7 & $5(71)$ & $5(71)$ & $5(71)$ & $7(100)$ \\
\hline Indole-positive Proteus & 13 & $11(85)$ & $11(85)$ & $6(46)$ & \\
\hline Total & 95 & $79 / 95(83)$ & $7895(82)$ & $68 / 89(76)$ & $24 / 26(92)$ \\
\hline
\end{tabular}

\footnotetext{
${ }^{a}$ Numbers in parentheses are percentages.
} 
TABLE 6. Effect of inoculum size on MIC of piperacillin and carbenicillin

\begin{tabular}{|c|c|c|c|c|c|c|}
\hline \multirow{3}{*}{ Organism } & \multicolumn{6}{|c|}{$\mathrm{MIC}(\mu \mathrm{g} / \mathrm{ml})$} \\
\hline & \multicolumn{3}{|c|}{ Piperacillin } & \multicolumn{3}{|c|}{ Carbenicillin } \\
\hline & $10^{7 a}$ & $10^{5}$ & $10^{3}$ & $10^{7}$ & $10^{5}$ & $10^{3}$ \\
\hline \multicolumn{7}{|c|}{ Klebsiella pneumoniae } \\
\hline 6064 & $>512$ & 16 & 4 & $>512$ & $>512$ & 512 \\
\hline 9296 & $>512$ & 16 & 4 & $>512$ & $>512$ & 512 \\
\hline 7111 & $>512$ & 4 & 2 & $>512$ & $>512$ & $>512$ \\
\hline 7942 & $>512$ & 16 & 8 & $>512$ & $>512$ & $>512$ \\
\hline \multicolumn{7}{|c|}{ Pseudomonas aeruginosa } \\
\hline 7005 & $>512$ & 8 & 4 & $>512$ & $>512$ & 512 \\
\hline 6691 & $>512$ & 8 & 4 & $>512$ & 512 & 128 \\
\hline 6506 & 16 & 4 & 4 & $>512$ & 512 & 256 \\
\hline 5460 & $>512$ & 32 & 4 & $>512$ & 32 & 16 \\
\hline \multicolumn{7}{|l|}{ Escherichia coli } \\
\hline 9603 & 256 & 8 & 8 & $>512$ & $>512$ & $>512$ \\
\hline 7700 & $>512$ & 128 & 32 & $>512$ & $>512$ & $>512$ \\
\hline 7487 & $>512$ & 64 & 32 & $>512$ & $>512$ & $>512$ \\
\hline 6454 & $>512$ & 32 & 4 & $>512$ & $>512$ & 512 \\
\hline \multicolumn{7}{|l|}{ Serratia marcescens } \\
\hline 4798 & 256 & 4 & 2 & 128 & 32 & 16 \\
\hline 5096 & $>512$ & 4 & 1 & $>512$ & 32 & 16 \\
\hline 0549 & 512 & 4 & 4 & $>512$ & $>512$ & $>512$ \\
\hline 5904 & $>512$ & 2 & 1 & 64 & 32 & 4 \\
\hline \multicolumn{7}{|l|}{ Enterococcus } \\
\hline 1711 & 4 & 4 & 2 & 512 & 512 & 512 \\
\hline 1630 & 8 & 4 & 2 & $>512$ & 512 & 512 \\
\hline 2433 & 8 & 4 & 4 & $>512$ & 512 & 512 \\
\hline 2411 & 8 & 4 & 4 & $>512$ & 512 & 256 \\
\hline
\end{tabular}

${ }^{a}$ Inoculum size of organisms (CFU/milliter) prepared from 18-h culture in Mueller-Hinton broth.

TABLE 7. Inhibitory index ${ }^{a}$

\begin{tabular}{|c|c|c|c|c|c|c|c|c|c|c|}
\hline \multirow[b]{2}{*}{ Agent } & \multirow{2}{*}{$\begin{array}{c}\text { Mean } \\
\text { peak } \\
\text { level } \\
(\mu \mathrm{g} / \mathrm{ml})\end{array}$} & \multicolumn{9}{|c|}{ Inhibitory index } \\
\hline & & $\begin{array}{l}\text { Pseudo- } \\
\text { monas } \\
\text { aeruginosa }\end{array}$ & $\begin{array}{c}\text { Escher- } \\
\text { ichia } \\
\text { coli }\end{array}$ & $\begin{array}{c}\text { Klebsiella } \\
\text { pneumoniae }\end{array}$ & $\begin{array}{c}\text { Serratia } \\
\text { mar- } \\
\text { cescens }\end{array}$ & $\begin{array}{l}\text { Proteus } \\
\text { mira- } \\
\text { bilis }\end{array}$ & $\begin{array}{l}\text { Indole- } \\
\text { positive } \\
\text { Proteus }\end{array}$ & $\begin{array}{l}\text { Enter- } \\
\text { obacter } \\
\text { sp. }\end{array}$ & $\begin{array}{l}\text { Bacter- } \\
\text { oides } \\
\text { fragilis }\end{array}$ & $\begin{array}{l}\text { Enter- } \\
\text { ococcus }\end{array}$ \\
\hline Piperacillin . & 128 & 16 & 16 & 16 & 16 & 16 & 16 & 16 & 16 & 16 \\
\hline Carbenicillin & 128 & 1 & 4 & $<0.5$ & 4 & 16 & 16 & 8 & 4 & 2 \\
\hline Gentamicin . & 4 & 0.5 & 4 & 4 & 4 & 4 & 4 & 4 & & \\
\hline Cephalothin & 16 & & 2 & 2 & & 2 & & & $2^{b}$ & \\
\hline Ampicillin . . & 16 & & 2 & & & 8 & & & & \\
\hline
\end{tabular}

${ }^{a}$ Ratio between the mean peak serum level of each antimicrobial agent and the MIC required to inhibit twothirds of each group of organisms.

${ }^{b}$ Cefoxitin (mean peak level $=32 \mu \mathrm{g} / \mathrm{ml}$ ).

cillin (Table 8). All 5 were $P$. aeruginosa isolates. Of the 13 amikacin-resistant organisms, 11 were inhibited by piperacillin and 8 were inhibited by carbenicillin. However, the MICs of aminoglycoside-resistant organisms susceptible to both piperacillin and carbenicillin were usually 2 - to 16 -fold lower for piperacillin than for carbenicillin.

Approximately one-third of the gram-negative bacilli tested were inhibited synergistically by the combination of piperacillin plus amikacin (Table 9). No synergy could be demonstrated against the six isolates of enterococci.

\section{DISCUSSION}

The results of these studies document piperacillin's broad spectrum of activity against gramnegative bacilli and the enterococcus. Except for $E$. coli, piperacillin inhibited $90 \%$ or more of the isolates in each group of organisms tested at 64 $\mu \mathrm{g} / \mathrm{ml}$ in agar, a clinically achievable blood level (private communication from Vincent A. Joy, Lederle Laboratories). Ueo et al. (12) also have reported recently on the in vitro effectiveness of piperacillin, but observed lesser activity against Escherichia coli, $K$. pneumoniae, S. marces- 
TABLE 8. Comparative activity of carbenicillin and piperacillin against aminoglycoside-resistant organisms

\begin{tabular}{|c|c|c|c|c|c|}
\hline \multirow[b]{2}{*}{ Organism } & \multirow[b]{2}{*}{ No. } & \multicolumn{4}{|c|}{ No. of strains growing with: } \\
\hline & & $\begin{array}{l}\text { Gentamicin } \\
(\geq 16)^{a}\end{array}$ & $\begin{array}{l}\text { Amikacin } \\
(\geq 32)\end{array}$ & $\begin{array}{l}\text { Carbenicillin } \\
(\geq 256)\end{array}$ & $\begin{array}{l}\text { Piperacillin } \\
\quad(\geq 256)\end{array}$ \\
\hline \multirow[t]{2}{*}{ Pseudomonas aeruginosa } & 9 & 9 & & 4 & 4 \\
\hline & 6 & & 6 & 1 & 0 \\
\hline \multirow[t]{2}{*}{ Serratia marcescens } & 9 & 9 & & 9 & 9 \\
\hline & 1 & & 1 & 1 & 1 \\
\hline Providencia stuartii & 9 & 9 & & 9 & 9 \\
\hline Escherichia coli ........... & 3 & & 3 & 1 & 1 \\
\hline Enterobacter sp. . . . . . . . . & 3 & & 3 & 1 & 1 \\
\hline
\end{tabular}

${ }^{a}$ MIC.

TABLE 9. Synergistic activity of amikacin and piperacillin

\begin{tabular}{|c|c|c|}
\hline Organism & No. & Synergy (\%) \\
\hline 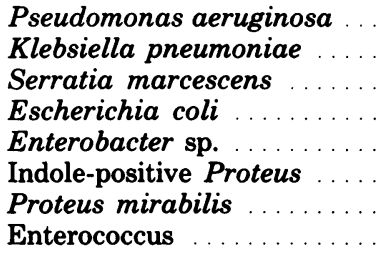 & $\begin{array}{r}14 \\
9 \\
8 \\
5 \\
6 \\
4 \\
3 \\
6\end{array}$ & $\begin{array}{l}5(36) \\
3(33) \\
3(38) \\
2(40) \\
2(33) \\
1(25) \\
0(0) \\
0(0)\end{array}$ \\
\hline Total & 55 & $16(29)$ \\
\hline
\end{tabular}

cens, and Enterobacter cloacae. The use of a different medium (heart infusion agar) and a slightly heavier inoculum $\left(5 \times 10^{5} \mathrm{CFU}\right)$ by the latter investigators may account for these differences. Except for the enterococcus, gram-positive organisms were not evaluated in our studies, but other investigators have noted piperacillin's in vitro activity against Staphylococcus epidermidis, Streptococcus pneumoniae, and Streptococcus pyogenes $(12 ; \mathrm{K}$. P. Fu and H. C. Neu, 10th Int. Cong. Chemother., Abstr. 71, 1977; T. C. Eickhoff and J. M. Ehret, 10th Int. Cong. Chemother., Abstr. 72, 1977; R. Jones, P. Fuchs, and A. Barry, Program Abstr. 17th Intersci. Conf. Antimicrob. Agents Chemother., Abstr. $318,1977)$. Like penicillin $G$, piperacillin is subject to hydrolysis in the presence of penicillinase and thus is less active than the cephalosporins against Staphylococcus aureus (12).

Piperacillin's in vitro activity compared favorably with that of other antimicrobial agents commonly used to treat infections caused by gram-negative bacillary organisms. Either on a weight basis or in terms of the inhibitory index, piperacillin was more active than carbenicillin against all organisms tested, especially $K$. pneumoniae, $P$. aeruginosa, the enterococcus, Serratia marcescens, and $B$. fragilis (Table 2). For these five organisms, piperacillin had a 4- ( $B$. fragilis) to 32 -fold (K. pneumoniae) increase in activity by weight over carbenicillin. Piperacillin's inhibitory activity was also similar to gentamicin's for most of the organisms tested (Table 3). Piperacillin had a higher inhibitory index than cephalothin against $K$. pneumoniae, $E$. coli, and Proteus mirabilis and than cefoxitin against $\boldsymbol{B}$. fragilis (Table 7). Finally, relative to ampicillin, piperacillin had greater inhibitory activity against $E$. coli and $P$. mirabilis (Table 2). Ueo et al. also observed greater activity for piperacillin compared with carbenicillin and ampicillin against gram-negative organisms susceptible to all three antimicrobial agents (12).

The specific mechanisms responsible for piperacillin's wide spectrum of antimicrobial activity have not been completely elucidated. As observed in this study and by other investigators (Fu and Neu, 10th Int. Congr. Chemother., Abstr. 71, 1977; N. A. Kuck and M. Forbes, 10th Int. Congr. Chemother., Abstr. 73, 1977), piperacillin's in vitro activity is influenced by the inoculum size, especially at higher inocula. Inactivation of piperacillin by large amounts of beta-lactamase is a likely explanation for this phenomenon (S. Mitsuhashi, Y. Fukuoka, T. Hayashi, and N. Matsubara, 10th Int. Congr. Chemother., Abstr. 75, 1977). At the same time, piperacillin is stable to the beta-lactamases produced by certain organisms resistant to carbenicillin, ampicillin, and cephalosporins (12). Piperacillin's increased accessibility to the target sites of beta-lactamase antibiotics (Mitsuhashi et al., 10th Int. Congr. Chemother., Abstr. 75, 1977) and inhibition of the induction of autolysins (K. Iida, S. Hirata, S. Nakamuta, and M. Koike, 10th Int. Congr. Chemother., Abstr. 70, 1977) may be additional factors contributing to its antibacterial activity. Further studies defining the mechanism of action of piperacillin are needed.

A number of potential clinical uses for piperacillin seem possible in view of the findings reported here. In terms of its antibacterial spectrum, piperacillin is similar to gentamicin. How- 
ever, gentamicin's usage has been limited by its potential nephrotoxicity and ototoxicity. Piperacillin, on the other hand, has been used in over 1,200 patients in Japan without significant renal or ototoxicity (private communication from Vincent A. Joy, Lederle Laboratories). Most side effects observed with piperacillin were skin rashes or gastrointestinal symptoms such as nausea, vomiting, and diarrhea. Thus, if further clinical trials can confirm its therapeutic efficacy with lessened toxicity, piperacillin could become an acceptable single-agent alternative to the aminoglycosides in the treatment of gram-negative infections. Relative to carbenicillin, piperacillin's greater activity on a weight basis may make it possible to use lower doses and thus avoid the untoward effects of sodium overload and hypokalemia observed with carbenicillin $(6,8)$. At the same time, piperacillin has the added advantage of significant activity against carbenicillin-resistant $K$. pneumoniae and amikacin-resistant permeability mutants. It may also be possible to take advantage of the potential synergistic activity of the piperacillin-aminoglycoside combination against $K$. pneumoniae as well as $P$. aeruginosa in the treatment of severe infections caused by these organisms. Thus, further clinical trials and comparative studies in humans to establish piperacillin's role in the treatment of bacterial infections are warranted.

\section{ACKNOWLEDGMENTS}

We thank Charles Hanson and Judith Johnston for performing the anaerobic susceptibility testing, Terrie Landis and the staff of the Clinical Microbiology Laboratories for their excellent technical assistance, and Richard D. Meyer for providing isolates from patients at the Wadsworth Veterans Administration Hospital, Los Angeles.

This study was supported by a grant from Lederle Laboratories.

\section{LTERATURE CITED}

1. Dhawan, V., E. Marso, W. J. Martin, and L. S. Young. 1977. In vitro studies with netilmicin compared with amikacin, gentamicin, and tobramycin. Antimicrob. Agents Chemother. 11:64-73.

2. Ericsson, H. M., and J. C. Sherris. 1971. Antibiotic sensitivity testing. Report of an international collaborative study. Acta Pathol. Microbiol. Scand. Sect. B, Suppl. 217, p. 90.
3. Ewing, W. H., and W. J. Martin. 1974. Enterobacteriaceae, p. 189-221. In E. H. Lennette, E. H. Spaulding, and J. P. Truant (ed.), Manual of clinical microbiology, 2nd ed. American Society for Microbiology, Washington, D.C.

4. Facklam, R. R. 1974. Streptococci, p. 96-108. In E. H. Lennette, E. H. Spaulding, and J. P. Truant (ed.), Manual of clinical microbiology, 2nd ed. American Society for Microbiology, Washington, D.C.

5. Gilbert, D. N., E. Kutscher, R. Ireland, J. A. Barnett, and J. P. Sanford. 1971. Effect of the concentrations of magnesium and calcium on the in vitro susceptibility of Pseudomonas aeruginosa to gentamicin. J. Infect. Dis. 124(Suppl.):S37-S45.

6. Hoffiman, T. A., and W. E. Bullock. 1970. Carbenicillin therapy of Pseudomonas and other gram-negative bacillary infections. Ann. Intern. Med. 73:178-187.

7. Hugh, R., and G. L. Gilardi. 1974. Pseudomonas, p. 250-269. In E. H. Lennette, E. H. Spaulding, and J. P. Truant (ed.), Manual of clinical microbiology, 2nd ed. American Society for Microbiology, Washington, D.C.

8. Klastersky, J., B. Vanderkelen, D. Danean, and $M$. Mathieu. 1973. Carbenicillin and hypokalemia. Ann. Intern. Med. 78:774-775.

9. Sabath, L. D., C. E. McCall, N. H. Steigbigel, and M. Finland. 1967. Synergistic penicillin combinations for treatment of human urinary tract infections, p. 149-155. Antimicrob. Agents Chemother. 1966.

10. Sutter, V. L., H. R. Attebery, and S. M. Finegold. 1974. Gram-negative nonsporeforming anaerobic bacilli, p. 388-395. In E. H. Lennette, E. H. Spaulding, and J. P. Truant (ed.), Manual of clinical microbiology, 2nd ed. American Society for Microbiology, Washington, D.C.

11. Tatum, H. W., W. H. Ewing, and R. E. Weaver. 1974. Miscellaneous gram-negative bacteria, p. 270-294. In E. H. Lennette, E. H. Spaulding, and J. P. Truant (ed.), Manual of clinical microbiology, 2nd ed. American Society for Microbiology, Washington, D.C.

12. Ueo, K., Y. Fukuoka, T. Hayashi, T. Yasuda, H. Taki, H. Tai, M. Tai, Y. Watanabe, I. Saikawa, and S. Mitsuhashi. 1977. In vitro and in vivo antibacterial activity of T-1220, a new semisynthetic penicillin. Antimicrob. Agents Chemother. 12:455-460.

13. Washington, J. A., and A. L. Barry. 1974. Dilution test procedures, p. 410-417. In E. H. Lennette, E. H. Spaulding, and J. P. Truant (ed.), manual of clinical microbiology, 2nd ed. American Society for Microbiology, Washington, D.C.

14. Weinstein, R. J., L. S. Young, and W. L. Hewitt. 1975. Comparison of methods for assessing in vitro antibiotic synergism against Pseudomonas and Serratia. J. Lab. Clin. Med. 86:853-862.

15. Wilkins, T. D., and S. Chalgren. 1976. Medium for use in antibiotic susceptibility testing of anaerobic bacteria. Antimicrob. Agents Chemother. 10:926-928.

16. Young, L. S., and W. L. Hewitt. 1973. Activity of five aminoglycoside antibiotics in vitro against gram-negative bacilli and Staphylococcus aureus. Antimicrob. Agents Chemother. 7:172-178. 